\title{
Review of Food and Feeding Habits of Some Synodontis Fishes in African Freshwaters
}

\author{
Edwine Yongo*, Jacob Iteba and Simon Agembe \\ Department of Fisheries \& Aquatic Sciences, University of Eldoret, Kenya
}

Submission: June 11, 2019; Published: July 01, 2019

Corresponding author: Edwine Yongo, Department of Fisheries \& Aquatic Sciences, University of Eldoret, P.o Box 1125-30100 Eldoret, Kenya

\begin{abstract}
This paper reviewed food and feeding habits of six Synodontis species in the African freshwaters and determined diet with respect to size (ontogenetic shift) and season. The variety of food substances found in the stomach of various Synodontis species from different African waters showed that the species are omnivorous feeders as the diet covers a wide spectrum of food ranging from various types of plankton to invertebrates, plants and small fish. The importance of phytoplankton, zooplankton and insects declined steadily with size of fish while the importance of macrophytes, fish fry and fish scales increased with size of fish. This review showed abundance of food for Synodontis fish in both the months of wet and dry seasons. The high diversity of the food composition in the stomachs of Synodontis fish species indicates a wide adaptability to the food and feeding habit in the water bodies in which they live. The scientific information obtained in this review is important for understanding of the trophic position of the Synodontis fish species in order to maintain proper balance and dynamics of the species in the African freshwaters.
\end{abstract}

Keywords: Synodontis; Feeding; Diet shift

\section{Introduction}

Fishes of the genus Synodontis (family Mochokidae) are commonly referred to as squeakers or upside-down catfishes. They are widely distributed in African freshwaters ranging from the Nile basin, Chad, Niger and West African regions. The genus has over 112 species some of which are commercially important [1]. The different Synodontis species vary in commercial status in different locations, many are important food fishes, and some have attractive hues and exhibit behavioral characteristics that make them potential ornamental candidates [2]. Synodontis are highly valued food fishes in Benin and contribute a significant proportion to the fishery of the rivers [3]. The two species, $S$. victoriae and S. afrofischeri, occur in Lake Victoria [4]. The smaller sized species $S$. afrofischeri tends to inhabit water $<20 \mathrm{~m}$ deep while $S$. victoriae is more numerous in deeper waters. $S$. victoriae are prized ornamental because of their striking pigmentation body patterns and upside-down swimming behavior [5,6]. Furthermore, like any other fish they play an important role by providing food for human consumption and employment opportunities for communities within Lake Victoria basin.

Synodontis schall (Bloch \& Schneider) is reported as the most tolerant species to adverse environmental conditions in the genus and it has the widest distribution in Africa [7]. It is commercially important in the inland waters of West Africa and is one of the species that can be seen in the fish markets throughout the year. Synodontis resupinatus Boulenger 1904, occur throughout most of the freshwaters of the Sub-Saharan Africa and the Nile River [8]. Synodontis nigrita (Curvier and Valenciennes, 1864) is one of the dominant and endemic Mochokids of Nigeria inland waters [9]. It supports a thriving commercial fishery in many West African Countries. S. nigrita is noted as a palatable fish with high protein content and is in great demand, however, its armor-like head makes it bony in structure [10]. Synodontis membranaceus has excellent flavor of flesh either fresh or dried as human food and perform important trophic role in their habitat where they serve as food for other commercially important fishes and hence the need for their conservation [11]. This paper reviewed food and feeding habits of six Synodontis species in the African freshwaters and determined diet with respect to size (ontogenetic shift) and season. An understanding of the food and feeding habits of fish is important for its management and successful culture.

\section{Food and feeding habits of Synodontis fishes}

\section{Food Composition}

The frequency of occurrence of food items in stomachs of S. nigrita, S. schall, S. resupinatus, S. membranaceus, S. victoriae and S. afrofischeri from different African waters are summarized 
in Table 1. In Ouémé River, Benin [3], macrophytes and algae were the most preferred food items by S. schall and S. nigrita. The proportion of eggs and fish scales was more important in the stomach contents of S. schall (40.4\%) compared to that of S. nigrita (1.6\%). However S. schall preferred molluscs, nematodes and insects than S. nigrita. Synodontis schall in Lake Chamo, Ethiopia [1], zooplankton (Copepod and Cladocera) had the highest occurrence in diet followed by fish scales (35.0\%) and Diptera insects (31.1\%). S. resupinatus in River Niger, Nigeria [2] majorly fed on macrophytes (41.7\%), sand grains (29.2\%) and algae (18.2\%). In Ogobiri River, Nigeria (Allison \& Youdubagha, 2013), the frequency of occurrence of the most important food items consumed by S. membraneceus were Cladocera (30.5\%), Insects (30.9\%) and Copepods (29.6\%). For S. victoriae in Lake Victoria, the most ingested food items included Caridina nilotica (57.1\%), Insects (22.3\%), Fish remains (19.3\%), Rastrineobola argentea (17.9\%) and detritus (13.9\%). The major food items for S. afrofischeri in Lake Victoria included R. argentea (34.0\%) and insects (23.1\%), followed by fish remains, worms, molluscs, haplochromines and algae.

Table 1: Frequency of occurrence of different food categories in stomachs of six Synodontis fishes: S. nigrita, S. schall, S. resupinatus, S. membranaceus, S. victoriae and S. afrofischeri.

\begin{tabular}{|c|c|c|c|c|c|c|c|c|}
\hline $\begin{array}{c}\text { Food } \\
\text { category }\end{array}$ & $\begin{array}{c}\text { S. nigrita } \\
\text { (Ouémé } \\
\text { River) [3] } \\
\mathbf{n}=839\end{array}$ & $\begin{array}{l}\text { S. schall } \\
\text { (Ouémé } \\
\text { River) [3] } \\
\mathbf{n = 2 8 0 7}\end{array}$ & $\begin{array}{l}\text { S. schall (L. } \\
\text { Chamo) [1] } \\
n=545\end{array}$ & $\begin{array}{c}\text { S.resupinatus } \\
\text { (River Niger) } \\
{[2] \mathrm{n}=60}\end{array}$ & $\begin{array}{c}S . \\
\text { membranaceus } \\
\text { (Ogobiri River) } \\
{[22] \mathrm{n}=95}\end{array}$ & $\begin{array}{c}\text { S. victoriae } \\
\text { (L. Victoria) } \\
\text { [6] } n=173\end{array}$ & $\begin{array}{l}\text { S. victoriae } \\
\text { (L. Victori) } \\
{[4] \mathrm{n}=373}\end{array}$ & $\begin{array}{c}S . \\
\text { afrofischeri } \\
\text { (L. Victoria) } \\
{[4] \mathrm{n}=293}\end{array}$ \\
\hline Macrophytes & 43.7 & 59.65 & 9.8 & 41.7 & 0 & 0 & 0 & 0 \\
\hline Algae & 45.63 & 35.1 & 0 & 18.24 & 0 & 0 & 0 & 0.6 \\
\hline Insects & 8.4 & 17.54 & 0 & 0.16 & 30.9 & 22.34 & 7.6 & 23.1 \\
\hline Diptera & 0 & 0 & 31.1 & 0 & 0 & 0 & 0 & 0 \\
\hline Odonata & 0 & 0 & 6.2 & 0 & 0 & 0 & 0 & 0 \\
\hline Coleoptera & 0 & 0 & 4.9 & 0 & 0 & 0 & 0 & 0 \\
\hline Other insects & 3.78 & 7.02 & 7.7 & 1.95 & 0 & 11.82 & 0 & 0 \\
\hline Fish scales & 1.56 & 40.35 & 35 & 0.16 & 0 & 8.47 & 0 & 0 \\
\hline Crustacea & 2.94 & 5.26 & 0 & 0.16 & 0 & 0 & 0 & 0 \\
\hline Rotifera & 0.02 & 5.45 & 15.6 & 0 & 0 & 0 & 0 & 0 \\
\hline Mollusca & 2.1 & 19.3 & 0 & 0 & 0 & 8.91 & 2.4 & 10.3 \\
\hline Nematoda & 2.52 & 12.28 & 0 & 0 & 0 & 0 & 0 & 0 \\
\hline Copepoda & 0 & 0 & 75.5 & 0 & 29.5 & 13.43 & 0 & 0 \\
\hline Cladocera & 0 & 0 & 76.5 & 0 & 30.5 & 10.51 & 0 & 0 \\
\hline Sand grains & 0 & 3.51 & 0 & 29.16 & 0 & 0 & 0 & 0 \\
\hline Mud & 12.18 & 7.02 & 0 & 1.63 & 0 & 0 & 0 & 0 \\
\hline Fish remains & 0 & 0 & 13.7 & 0 & 0 & 0 & 19.3 & 11.5 \\
\hline Fish eggs & 1.56 & 40.35 & 3.8 & 0 & 0 & 0 & 0 & 0 \\
\hline Diatoms & 0 & 0 & 6.4 & 0 & 0 & 0 & 0 & 0 \\
\hline Detritus & 0 & 0 & 0 & 0 & 0 & 13.87 & 0 & 0 \\
\hline C. nilotica & 0 & 0 & 0 & 0 & 0 & 0 & 57.1 & 7.1 \\
\hline R. argentea & 0 & 0 & 0 & 0 & 0 & 0 & 17.9 & 34 \\
\hline E. profundus & 0 & 0 & 0 & 0 & 0 & 0 & 0 & 0 \\
\hline Haps & 0 & 0 & 0 & 0 & 0 & 0 & 1.4 & 0.6 \\
\hline Worms & 0 & 0 & 0 & 0 & 0 & 0 & 0.5 & 11.5 \\
\hline Unidentified & 2.94 & 26.32 & 0 & 6.84 & 9 & 0 & 0.5 & 0 \\
\hline
\end{tabular}

\section{Ontogenetic diet shift}

Ajah et al., 2006 analyzed 100 specimens of S. nigrita from Cross River Estuary in Nigeria and found that juveniles (12-20 cm TL) were predominantly mud dwelling, feeding on nematode worms (91\%), diatoms (7\%) and crustaceans (1\%), whilst adults (21-25 cm TL) were found to be predominantly planktotrophic, their diets comprising 50\% diatoms and 50\% crustaceans
(Figure 1). S. membranaceus from Jebba Lake in Nigeria (Olufemi, 2007), showed a progression from detritivorous diets in fish below $20 \mathrm{~cm}$ SL through a transitional planktivorous diets in fish between $20-27 \mathrm{~cm}$ SL to a predominantly insectivorous diets in fish above $27 \mathrm{~cm}$ SL (Figure 2). The figure further shows the relative importance index of Aspatharia, plant parts, seeds and Coleopteran larvae increased with increase in fish size. For S. schall from Lake Chamo in Ethiopia, the importance of diatoms, 
zooplankton and insects declined as the size of fish increased, whilst that of scales increased with increase in fish size (Figure 3). Zooplankton contributed $68.1 \%$ of the food consumed by S. schall of size 10.0-14.49 cm FL, but they contributed only $12.5 \%$ of the total volume of food consumed in 35.0-39.9 cm FL size class. Insects constituted $22.0 \%$ of the total volume of food consumed by 10.0-14.9 cm FL, but their contribution declined sharply with the size of the fish and constituted only $3.8 \%$ of the total volume of food eaten by the $35.0-39.9 \mathrm{~cm}$ group. No diatoms were consumed by fish greater than $25 \mathrm{~cm}$ FL size class. On the other hand, the volume of fish scales, fish fry and macrophytes consumed by S. schall increased with size. No fish scales were consumed by 10.0-14.9 cm FL size class. In 15.5-19.9 cm FL size class, fish scales contributed only $5.5 \%$ of the total volume of food eaten, but in 35.0-39.9 cm FL size class the contribution was $50.6 \%$ of the total volume eaten.

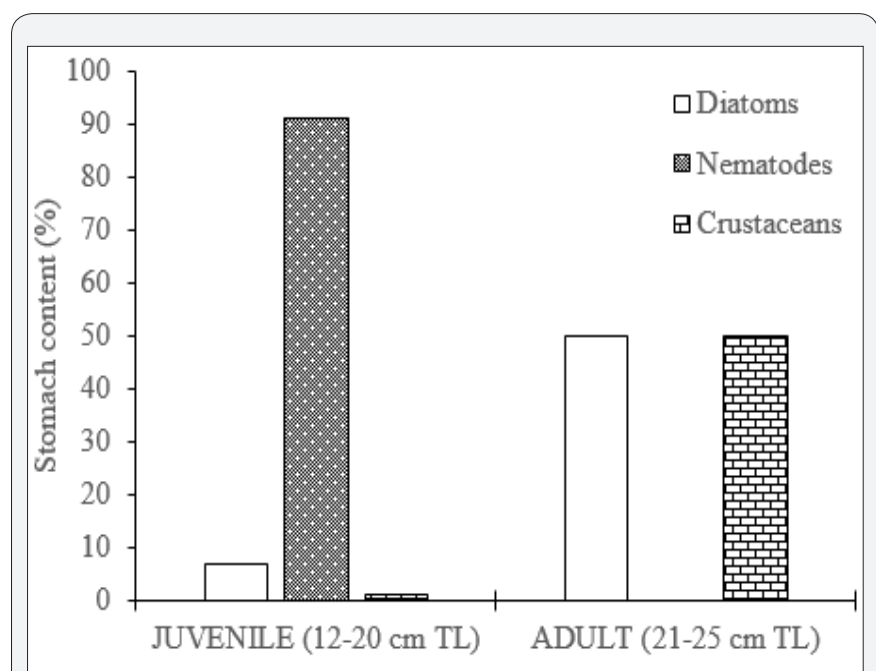

Figure 1: Percentage composition of the stomach content of juvenile and adult S. nigrita from Cross River Estuary, Nigeria (data adopted from Ajah et al., 2006).

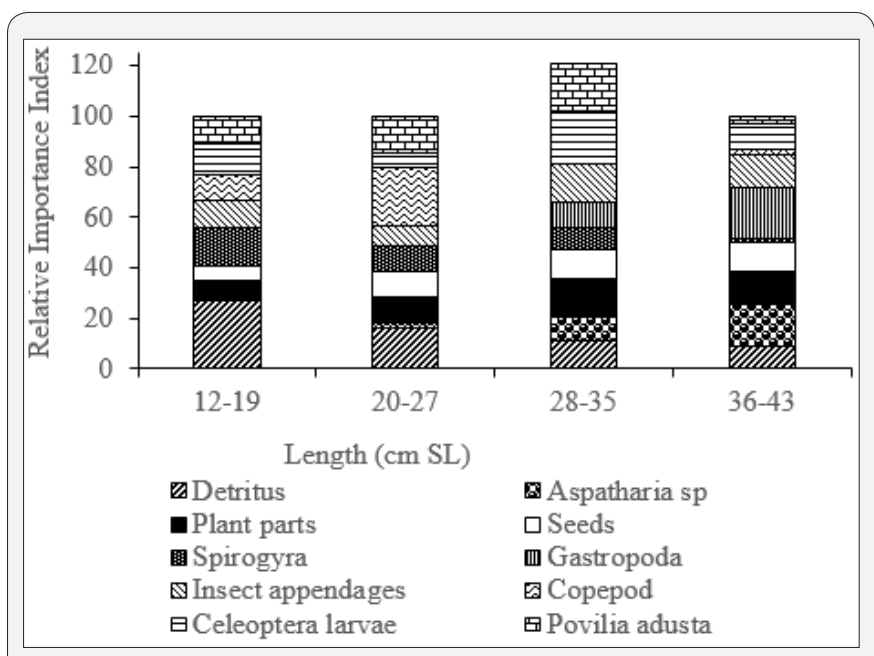

Figure 2: Relative Importance Index of major food items in the stomach of various size groups of $S$. membranaceus from Jebba Lake, Nigeria (data adopted from Olufemi, 2007; n=1208).

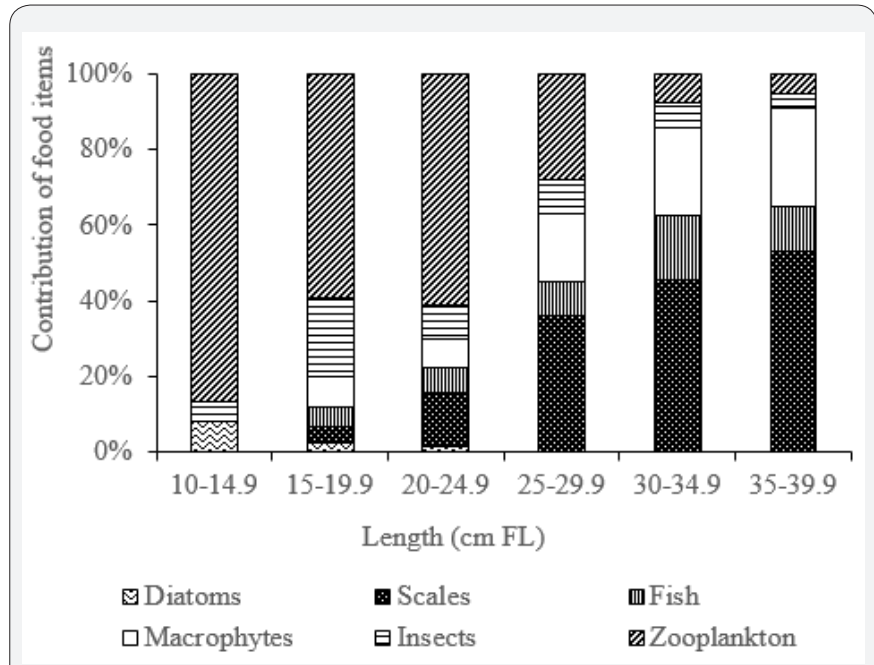

Figure 3: Percentage contribution of different food items consumed at different size classes of S. schall in Lake Chamo. (data adopted from Dadebo et al., 2012).

\section{Feeding in relation to season}

S. membranaceus from Jebba Lake, Nigeria extensively consumed detritus, P. adusta, coleopteran larvae, copepods, seeds and plant parts during the rainy season (Figure 4), whilist it consumed more gastropds, Spyrogyra and Aspatharia during dry season. For Synodontis victoriae, Plant detritus (Index of preponderance, $\mathrm{Ip}=24.0 \%$ ) and Copepoda (Ip = 19.3\%) dominated the diet in the dry season (Figure 5), while Chironomids ( $\mathrm{Ip}=24.0 \%$ ) dominated the diet during the rainy season.

\section{Discussion}

The variety of food items found in the stomach of six Synodontis species from different African freshwaters shows that the species are omnivorous feeders as the diet covers a wide spectrum of food ranging from various types of plankton to invertebrates, plants and small fish (Table 1). This agrees with the finding of Lauzanne (1988) who considers the Synodontis genus as eclectic. This high diversity of the food composition of Synodontis species indicates a wide adaptability to the habitats in which they live. This is an important strategy for survival and an advantage over the fish species competing for a specific food item $[12,13]$. A clear morphological explanation for its feeding versatility may be due to the ventral location of the mouth of Synodontis species which encourages a detritivorous mode of feeding while the simple horny structures around the mouth enable it to adapt to filter feeding. These structures also help Synodontis to gnaw at any hard plant tissue which form part of its rich diet [14].

The diversity in prey preference of fish in all the size categories could be due to partitioning of food resource in a bid to avoiding intraspecific competition. This plasticity in diet composition of Synodontis species reflects the availability 
of preferred prey organisms within a niche. The same reason could also be advanced for the progressive decline or increase in relative importance of the food items, as the fish grew older (Figure 1-3). The establishment of detritus as the main food items in the juveniles (12-19 cm SL) suggests a filter feeding habit. The ventral location of the mouth encourages detritivores mode of feeding. However, the inclusion of varied and large size food items in larger specimens indicated a switch from a filter feeding to increased reliance or active predation on appropriately sized prey that are probably selected individually. This may have been informed by the development of strong pharyngeal teeth and jaws. The diversity thus offered in the dominant food items as well as mode of feeding agreed with Fagbenro [15]. The switch from filter feeding to a predatory habit with increasing fish size is a common phenomenon in catfishes [16,17]. Also, the progression from detritivorous diets through a transitional planktivorous phase to active predation on relatively biggersized prey with increasing fish size agrees with the observations of Ochieng [18] and Fagbenro [15] that catfishes show a high degree of plasticity in their diets utilizing different food items as they grow.

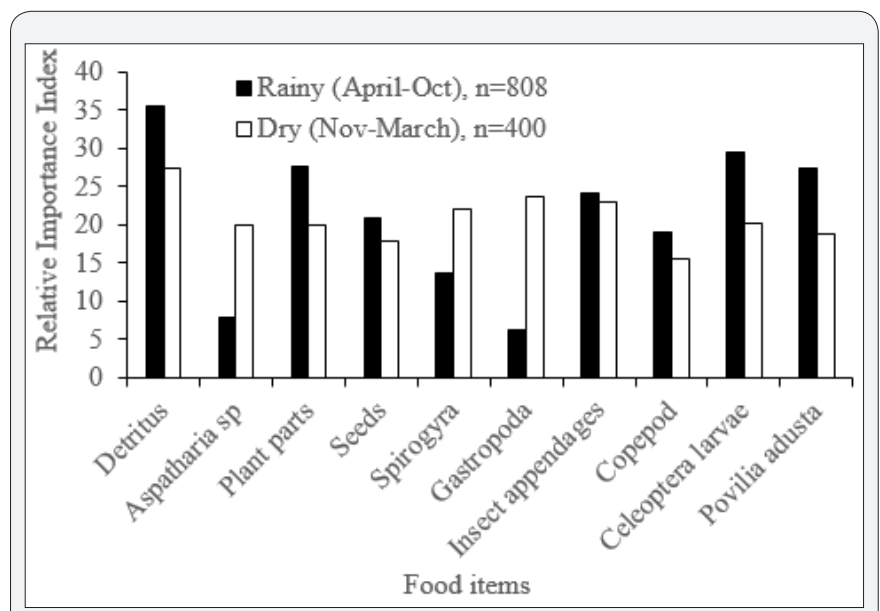

Figure 4: Seasonal variation in relative importance of the major food items in the stomach of $S$. membranaceus from Jebba Lake, Nigeria (data adopted from Olufemi, 2007).

The transition from insectivorous diets in the rainy season to benthophagus diet in the dry season (Figures 4 \& 5) is an indication of food selectivity depending on the relative abundance of available food as well as the size spectrum. Changes in fish diet associated with size and in relation to seasonal availability have been reported by Odum \& Anuta [19] and Saliu [20]. The increase in the quantitative composition of insects and their parts during the rainy season is attributed to the life history patterns of the insects and probably to the foraging efficiency of Synodontis species [21]. Detrital particles together with allochthonous food such as plant seeds washed by flood from the surrounding vegetation into the water bodies might have been responsible for the high incidence of each of these diets during the rainy season. The feeding on plant detritus and copepods during the dry season could be attributed to the poor food resources at this period and the dominance of Chironomids may be linked to the emergence of insects during the wet season $[22,23]$.

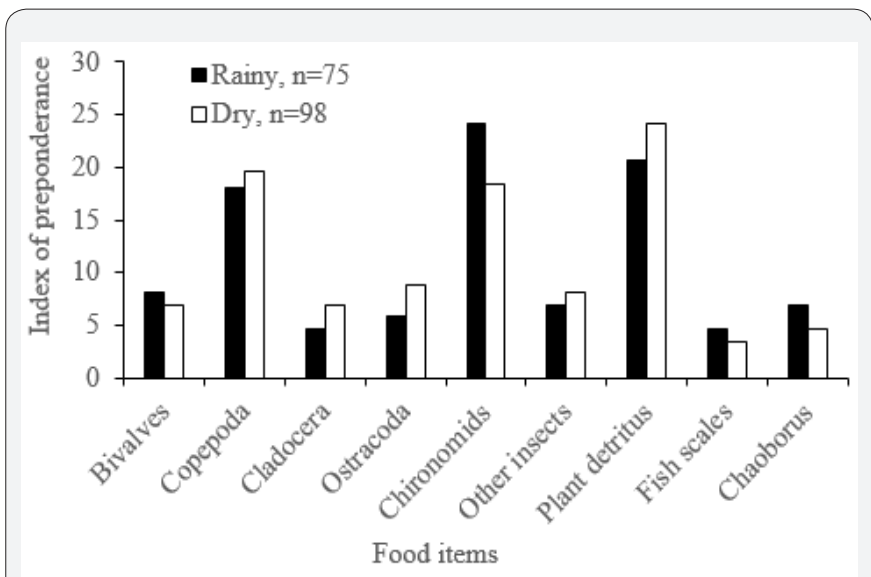

Figure 5: Seasonal variation in diet of S. victoriae from Lake Victoria, Kenya (data adopted from Wanyanga et al., 2016).

\section{Conclusion}

The feeding behavior of different Synodontis species from different African waters shows that the species are omnivorous, feeding on a wide variety of food items. The importance of phytoplankton, zooplankton and insects declined steadily with size of fish while importance of macrophytes, fish fry and fish scales increased with size of fish. This review showed abundance of food for Synodontis fish in both the months of wet and dry seasons. The high diversity of the food composition in the stomachs of Synodontis fish species indicated a wide adaptability to the food and feeding habit in the water bodies in which they live. The scientific information obtained in this review is important for understanding of the trophic position of the Synodontis fish species in order to maintain proper balance and dynamics of the species in the African freshwaters.

\section{References}

1. Dadebo E, Gebre-Mariam Z, Ahlgren G (2012) Feeding habits of the Catfish Synodontis schall (Bloch \& Schneider) (Pisces: Mochokidae) with emphasis on its scale eating habits in Lake Chamo, Ethiopia. Ethiopian Journal of Biological Sciences 11(2): 117-132.

2. Adeyemi S O (2010) Food and feeding habits of Synodontis resupinatus (Boulenger, 1904) at Idah area of River Niger, Kogi state, Nigeria. Animal Research International 7(3): 1281-1286.

3. Lalèyè $\mathrm{P}$, Chikou $\mathrm{A}$, Gnohossou P, Vandewalle $\mathrm{P}$, Philippart JC, et al. (2006)Studies on the biology of two species of catfish Synodontis schall and Synodontis nigrita (Ostariophysi: Mochokidae) from the Ouémé River, Bénin. Belg J Zool 136(2): 193-201.

4. Elison M V, Mlaponi E, Musiba M J, Ngupula G W, Kashindye B B, et al. (2018) Changes in the Diet of Synodontis victoriae and Synodontis afrofischeri in Lake Victoria, Tanzanian waters. African Journal of Tropical Hydrobiology and Fisheries 16: 10-15.

5. Yongo E, Wairimu A (2018) Studies on the Biology of Synodontis victoriae in the Nyanza Gulf of Lake Victoria, Kenya. Journal of Fisheries \& Aquaculture 9(2): 1-3. 
6. Wanyanga A, Yongo E, Mwangudza P (2016) Diet of Synodontis victoriae (Mochokidae) from Kunya Beach Lake Victoria, Kenya. International Journal of Fisheries \& Aquatic Research 1: 11-15.

7. Akombo P M, Akange E T, Adikwu I A, Araoye P A (2014) Lengthweight relationship, condition factor and feeding habits of Synodontis schall (Bloch and Schneider, 1801) In river Benue at Makurdi, Nigeria. International Journal of Fisheries and Aquatic Studies 1(3): 42-48.

8. Friel JP, Vigliotta TR (2006) Synodontis acanthopera, a new species from the Ogôoué River system, Gabon with comments on spiny ornamentation and sexual dimorphism in Mochokid catfishes (Siluriformes: Mochokidae). Zootaxa 1125: 45-56.

9. Olele NF, Etim L (2011) Some aspects of the Biology of Synodontis nigrita (Curvier and Valencienes, 1864) in Onah Lake, Asaba, Nigeria. Journal of Agricultural and Biological Science 6: 56-63.

10. Olojo EAA, Olurin KB, Osikoya OJ (2003) Food and feeding habits of Synodontis nigrita from the Osun River, SW Nigeria. NAGA, WorldFish Center Quarterly 26: 421-424.

11. Olufemi DO (2007) The influence of size, sex and season on the feeding regime of Synodontis membranaceus (Osteichthyes: Mochokidae) in Jebba Lake, Nigeria. Pakistan Journal of Biological Sciences 10(20): 3644-3649.

12. Paugy D (1994) Ecologie des poissons tropicaux d'un cours d'eau temporaire (Baoulé, haut basin du Sénégal au Mali): adaptation au milieu et plasticité du régime alimentaire. Revue Hydrobiologie Tropicale 27: 157-172.

13. Lévêque C (1997) Biodiversity dynamics and conservation: the freshwater fish of tropical Africa. In: Cambridge University Press, United Kindom, p. 438.

14. Welcomme RL (1979) Fisheries Ecology of Floodplain Rivers. In: Longman, London, p. 317.
15. Fagbenro OA (1992) The dietary habits of the Clariid catfish, Heterobranchus bidorsalis in Owena reservoir, Southern Nigeria. Trop Zool 5: 111-117.

16. Lowe-McConnel RH (1975) Fish communities in tropical freswaters: Their distribution, Ecology and Evolution. In: Longman, London, p. 337.

17. Welcomme RL (1985) Fisheries Ecology of Floodplain Rivers. In: Longman, London, p. 317.

18. Ochieng J (1982) Reproductive biology and feeding ecology of predatory siluroid catfish: Bagrus docmac Forskall (Pisces: Bagridae) in Winam Gulf of Lake Victoria, East Africa. M.Sc. Thesis, University of Nairobi, Kenya.

19. Odum $O$ and Anuta M (2001) The food and feeding habits of Phractolaemus ansorgii (Boulenger) from Warri River, Nigeria. J Aquat Sci 16: 18-21.

20. Saliu JK (2002) Size, sex and seasonal dynamics in the dietary composition of Brycinus nurse (Pisces: Characidae), from Asa Reservoir, Ilorin Nigeria. Rev Biol Trop 50: 233-238.

21. Ajah P O, Georgewill M N, Ajah M 0 (2006) The food and feeding habits of five freshwaters and brackish-water fish species in Nigeria. African Journal of Aquatic Science 31(2): 313-318.

22. Allison M E, Youdubagha SE (2013) Preliminary studies on the food and feeding habits of Synodontis membraneceus from Ogobiri River, Nigeria. Proceedings of $28^{\text {th }}$ Annual Conference 233-236.

23. Lauzanne L (1988) Les habitudes alimentaires des poisons deau douce africains. In: Lévêque C, MN Bruton, GW Ssentongo (eds), Biologie et écologie des poisons d'eau douce africains, Orstom, Paris pp. 221-242.

\begin{tabular}{|l|}
\hline \multicolumn{1}{|c|}{ Your next submission with Juniper Publishers } \\
will reach you the below assets \\
- Quality Editorial service \\
- Swift Peer Review \\
- Reprints availability \\
- E-prints Service \\
- Manuscript Podcast for convenient understanding \\
- Global attainment for your research \\
- Manuscript accessibility in different formats \\
( Pdf, E-pub, Full Text, Audio) \\
- Unceasing customer service \\
Track the below URL for one-step submission \\
https://juniperpublishers.com/online-submission.php
\end{tabular}

